\title{
Critical Race Theory, Feminism, and Disability: Reflections on Social Justice and Personal Identity
}

\begin{abstract}
ADRIENNE ASCH ${ }^{1}$
Since the passage of the Americans with Disabilities Act, those who fight for disability rights can acknowledge some progress in the situation of people with disabilities but can also recognize that the insights from critical race theory and feminism have lessons for the disability rights movement as well. This article considers the application of critical race theory and feminist theory to such topics as who should be able to use the anti-discrimination provisions of the $A D A$, how to evaluate the interaction of impairment with environment, differences among impairments and environments and their implications for inclusion of people with disabilities in society, the merits of integration as a goal, and disability-consciousness as part of personal identity.
\end{abstract}

\section{INTRODUCTION}

[] ndividuals with disabilities are a discrete and insular minority who have been ... subjected to a history of purposeful unequal treatment, and relegated to a position of political powerlessness in our society ... resulting from... assumptions not truly indicative of the... ability of such individuals to participate in, and contribute to, society. ${ }^{2}$

These words form part of the findings and purposes section of the Americans with Disabilities Act (ADA), the 1990 law that is intended to protect people with disabilities from discrimination in, and promote their access to, employment, governmental services, and public accommodations. In the more than ten years since its passage, the law has been subject to analysis and critique from proponents and detractors ${ }^{3}$ as well as significant challenge in the courts. ${ }^{4}$

${ }^{1}$ Ph.D. Henry R. Luce Professor of Biology, Ethics and the Politics of Human Reproduction, Wellesley College. I wish to thank Ruth Colker for inviting me to examine the lessons of critical race theory and feminism for disability theory and policy. The invitation, and our several conversations as I grappled with these questions, have proved very provocative and stimulating for me, and I can only hope that this essay captures some of what I have learned from our work together.

Many thanks go to Taran Jefferies, who not only provided superb logistical and research assistance and became a pro at Bluebook citation form, but also provided intellectual stimulation through our discussion of these ideas and moral support that prevented me from deciding the task was too great to accomplish.

2 Americans with Disabilities Act, 42 U.S.C. § 12111(a)(7) (1994).

${ }^{3}$ See generally 22 BERKELEY J. EMP. \& LAB. L. (2000); 549 ANNALS AM. ACAD. POL. \& SOC. SCI. (1997); AMERICANS WITH DISABILTIES: EXPLORING IMPLICATIONS OF THE LAW FOR INDIVIDUALS AND INSTITUTIONS (Leslie Pickering Francis \& Anita Silvers eds., 2000) (each containing articles analyzing and critiquing the $\mathrm{ADA}$ ). 
The writings of many critical race theorists suggest that what disability scholars, activists, and legal advocates find so discouraging in court decisions,

${ }^{4}$ On February 21, 2001, as this essay is being completed, the Unites States Supreme Court handed down its opinion in a case testing the extent of Congress's power to impose obligations upon the states. As reported in the New York Times,

The Supreme Court today carved out a new area of immunity for the states from the reach of federal civil rights law, ruling that state employees cannot sue for damages for violations of the Americans With Disabilities Act.

The 5-to- 4 vote was the same by which the court, in a series of decisions over the past six years, has constricted the power of Congress and correspondingly expanded the sphere of state immunity to a degree unmatched in the modern era.

…

In overtuming the appeals court's ruling today, Chief Justice William H. Rehnquist's majority opinion concluded that the effort to open the states to lawsuits exceeded Congress's authority.

Linda Greenhouse, Justices Give the States Immunity from Suits by Disabled Workers, N.Y. TIMES, Feb. 22, 2001, at A1.

At least as disturbing as the ruling is the majority's claim that, "[e]ven if it were to be determined that the half a dozen relevant examples from the record showed unconstitutional action on the part of States, these incidents taken together fall far short of even suggesting the pattern of unconstitutional discrimination on which $\S 5$ legislation must be based." Univ. of Ala. at Birmingham Bd. of Trs. v. Garrett, No. 99-1240, 2001 U.S. LEXIS 1700, at *5 (Feb. $21,2001)$. This claim is vigorously disputed in Justice Breyer's dissenting opinion. Garrett, 2001 U.S. LEXIS 1700, at *38-42. Losing this case, as the amici curiae discuss, erodes the protection of people with disabilities from conduct by state governments that historically have been arguably as segregationist and discriminatory as Jim Crow laws were for AfricanAmericans in the pre-civil rights South. See Brief of Amici Curiae in Support of Respondents, Univ. of Ala. at Birmingham Bd. of Trs. v. Garrett, 193 F.3d 1214 (11th Cir.) (No. 99-1240).

It is also worth noting the majority's attitude toward people with disabilities as captured by the following remarks: "Thus, the Fourteenth Amendment does not require States to make special accommodations for the disabled, so long as their actions toward such individuals are rational. They could quite hardheadedly -and perhaps hardheartedly—hold to job-qualification requirements which do not make allowance for the disabled." Garrett, 2001 U.S. LEXIS 1700, at *4.

Fortunately, as Ruth Colker points out in this personal communication of October 11, 2000 , it does not entirely preclude people with disabilities from winning suits against state governments:

The correct technical explanation is that Garrett is about whether Congress has the authority to provide a private right of action for damages in actions brought by individuals against the state. Even if the plaintiff loses in Garrett, the federal government can still enforce ADA Title II. In addition, a private individual can still sue for injunctive relief. Finally, it is also the case that section 504 will still be fully available.

Letter from Professor Ruth Colker, Grace Fern Heck Faust Chair in Constitutional Law, The Ohio State University College of Law, to Adrienne Asch, Henry R. Luce Professor of Biology, Ethics and the Politics of Human Reproduction, Wellesley College (Oct. 11, 2000) (on file with author). 
lackluster agency enforcement, ${ }^{5}$ and public opposition is exactly the institutional response that should be expected. Central to critical race theory (CRT), is the view that racism is not aberrant but rather the natural order of American life. Describing the major points of the theory, Richard Delgado writes "Because racism is an ingrained feature of our landscape, it looks ordinary and natural to persons in the culture.... [W] hite elites will tolerate or encourage racial advances for blacks only when they also promote white self-interest." 6

There are many valuable messages to be gained from post-civil-rights-era CRT and feminist writing, and thus this essay can examine only a few topics with resonance for disability. To summarize my principal contentions, let me suggest the following: Much of the message of CRT is skeptical about achieving the kind of social transformation that would enable historically excluded groups to achieve and maintain a valued place in American life. The early civil rights strategy of fighting for school integration, integrated neighborhoods, and affirmative action in employment was a strategy that, at best, could help only some people of color to improve their lives. Even for those who could gain material improvements, the dream of integration and a society without racial consciousness itself contained views that endangered the self-esteem and social cohesion of people of color. To the extent that this same message applies to the fight for social change for people with disabilities, I share some of the skepticism about whether the goals are attainable. However, I am not ready to abandon the quest for a society in which human beings are appreciated for abilities and talents, assisted based upon their needs, and where differences in skin color, gender, sexual orientation, and health status are not occasions for exclusionary or pejorative treatment. Like the integrated society discussed by Alan Freeman ${ }^{7}$ and

5 'Enforcement efforts seem more focused on 'micro,' individual cases. This means lost opportunities, because findings at the individual level often do not lead to an examination of larger systemic issues. Overall, the federal enforcement effort has been uneven, lacking in robustness, and suffering from low visibility in many areas." NAT'L COUNCL ON DISABLTYY, PROMISES TO KEEP: A DECADE OF FEDERAL ENFORCEMENT OF THE AMERICANS WITH DISABILITIES ACT 4-5 (2000).

${ }^{6}$ CRIMCAL RACE THEORY: THE CUTTING EDGE, at xiv (Richard Delgado ed., 1995) [hereinafter CRT: THE CUTTING EDGE]. The pervasiveness of disparate, unequal, and pejorative treatment of people with disabilities in the United States is documented not only in Congress's findings and purposes section of the Americans with Disabilities Act, but, as applied to the actions of state governments particularly, in several amici curiae briefs submitted in the Garrett case. I will not try to further document the persistence of discrimination based on disability, but will confine my discussion to the lessons to be leamed from the legal scholarship of feminists and critical race theorists as they apply to disability.

${ }^{7}$ Alan David Freeman, Legitimizing Racial Discrimination through Antidiscrimination Law: A Critical Review of Supreme Court Doctrine, in CRITICAL RACE THEORY: THE KEY WRITINGS THAT FORMED THE MOVEMENT 29, 35 (Kimberlé Crenshaw et al. eds., 1995) [hereinafter CRT: THE KEY WRITINGS]: 
the thought experiment of philosopher Richard Wasserstrom, ${ }^{8}$ but rejected by critical race theorists such as Gary Peller, ${ }^{9}$ I am interested in achieving a society where eyesight is no more consequential for life chances than is eye color. The ideals I espouse here do not commit me to claiming that non-social consequences of being sighted or blind are identical to whether one has blue or brown eyes; however, they do commit me to putting forth an argument about disability and about social justice that appreciates similarities and differences among people with impairments, and between people with impairments and people of other discriminated-against groups. ${ }^{10}$

\section{PERSPECTIVES AND STORIES AS DATA}

Critical race theory and feminism contend that the perspectives of the discriminated-against, oppressed individual or group must be better understood by the larger society, and that the law should look not to wrongs of perpetrators but to helping those who have been victims of discrimination. In different words Alan Freeman, ${ }^{11}$ Mari Matsuda, ${ }^{12}$ and Patricia Williams ${ }^{13}$ all contend that the public and the courts as the representatives of society, must understand the experiences and responses of people who are regularly mistreated because of

A second and slightly less extreme version of the utopia posits a society in which racial identification is still possible, but no longer relevant to anyone's thinking or generalizations about anyone else... . Race would have become functionally equivalent to eye color in contemporary society. In yet a third version of the integrated society, racial identification persists as a cultural unifying force for each group, equivalent to an idealized model of religious tolerance. Each group respects the diverse character of every other group, and there are no patterns of domination or oppression between different groups.

8 Richard A. Wasserstrom, Racism and Sexism, in PHILOSOPHY AND SOCIAL ISSUES 11 (1980), cited in Anna Stubblefield, Racial Identity and Non-Essentialism about Race, 21 Soc. THEORY \& PRAC. 341, 368 n.7 (1995).

${ }^{9}$ Gary Peller, Race-Consciousness, in CRT: THE KeY WRITINGS, supra note 7, at 127.

${ }^{10}$ My discussion reflects only my own views on these very controversial topics. I represent no organization of people with disabilities in this essay, nor do I claim that all of my views are likely to be shared by the majority of theorists of disability who might evaluate similarities and contrasts with critical race theory or contemporary feminism. Throughout this discussion, I attempt to indicate where I believe many other disability studies/disability rights theorists share my views, and where I suspect that I am in a minority.

11 See supra note 7.

${ }^{12}$ Mari Matsuda, Looking to the Bottom: Critical Legal Studies and Reparations, in CRT: THE KEY WRITNGS, supra note 7, at 63 (Kimberlé Crenshaw et al. eds., 1995).

13 Patricia J. WILliams, The AICHEMY OF RACE AND Rights (1991). 
their "race."14 Reading of Patricia Williams being denied the opportunity to shop at a department store, ${ }^{15}$ or of how her friend, also African-American, was ignored and then nearly arrested when she asked to have spoiled milk taken off her restaurant bill, ${ }^{16}$ and of how their perspectives were discounted by others, I recoil with horror. I also recognize a painful similarity of small and large insults and of having those insults routinely discounted and re-interpreted by others so that I am wrong, I am too sensitive, or I am unfair to others "who are only trying to help." Much of the daily discrimination faced by people with disabilities is not the overt hostility of being shot at or lynched, although the institutionalization, involuntary sterilization, and school exclusion documented in University of Alabama at Birmingham Board of Trustees v. Garrett are blatant enough; rather, it is the experience of being denied the opportunity to play the social roles expected of one's nondisabled age-peers. Many commentators note that people with disabilities are expected to play no adult social role whatsoever; 17 to be perceived as always, in every social interaction, a recipient of help and never a provider of assistance; 18 and to be more disliked by nondisabled others if they are clearly competent than if they are perceived as incompetent at a task.19

Much personal narrative and social science writing about the experience of having a disability includes stories of indignities at the hands of strangers, neighbors, co-workers, friends, and family ${ }^{20}$-and then having to be told that your interpretation is always wrong. 21 The ADA may prevent a local health club

${ }^{14}$ I put the term "race" in quotes because the concept of race is itself a disputed one in critical race theory, as the concepts of "impairment," "disability," and "normality" are disputed among disability scholars as will be discussed later in this essay.

15 WLLIAMS, supra note 13 , at 44-45.

16 Id. at 56-57.

17 See JOHN GLIEDMAN \& WILIIAM ROTH, THE UNEXPECTED MINORTYY: HANDICAPPED CHIIDREN IN AMERICA 261-63 (1980).

${ }^{18}$ Michelle Fine \& Adrienne Asch, Disability beyond Stigma: Social Interaction, Discrimination, and Activism, 44 J. SOC. IsSUES 1, 3, 12 (1988).

${ }^{19}$ Irwin Katz et al., Attitudinal Ambivalence and Behavior toward People with Disabilities, in ATTIUUDES TOWARD PERSONS WTTH DisABIIIIES 47, 53 (Harold E. Yuker ed., 1988).

20 Illustrative are the accounts of social interactions reported in the classic works: ERVING GOFFMAN, STIGMA: NOTES ON THE MANAGEMENT OF SPOLLED IDENTITY (1963); ORDINARY MOMENTS: THE DISABLED EXPERIENCE (Alan J. Brightman ed., 1984); Marilyn J. Phillips, Damaged Goods: Oral Narratives of the Experience of Disability in American Culture, 30 SOC. SCI. \& MED. 849 (1990); JOHN HOCKENBERRY, MOVING VIOLATIONS: WAR ZONES, WHEELCHAIRS, AND DECLARATIONS OF INDEPENDENCE (1995).

${ }^{21}$ Some examples of events that occurred during a two-week period while this essay was my main intellectual focus, and therefore causing me to be especially aware of the impact of routine events: I was asked by an examining physician whether, because I was blind, I needed her assistant to "come in and help you get dressed"; I was told by a bus driver and several 
or public pool from turning me away if I go to exercise or swim, but it will do nothing to help me persuade a group of new friends that I could join them for a carefree afternoon at a lake. To accomplish that I must be prepared to provide my athletic credentials and convince them that they are not "responsible" for my safety. These indignities may be analogous to the unconscious racism captured poignantly in the writing of Charles $\mathrm{R}$. Lawrence, III, describing what it was like to be a five-year-old Black child amidst a White teacher and White classmates all enjoying the story of Little Black Sambo and then to have your daughter's fouryear-old friend tell you, thirty years later, that the same story is his favorite. ${ }^{22}$

Like the academic feminists and CRT authors I cite, a growing number of professionals with disabilities, including myself, can point to professional recognition and the joys of doing work we love as well as its relative financial security and social status. Yet like these others, we have all-too-frequent reminders that we are unanticipated participants in workshops or conferences or unexpected guests at social gatherings. Sitting beside a stranger waiting for a lecture to begin at an academic conference, the stranger whispers loudly not "Hello, my name is Carol," but "Let me know how I can help you." What help do I need while waiting for the speaker to begin? Why not introduce herself, rather than assume that the only sociability I could possibly want is her help? When I respond by saying that she can let me know if I can help her, she does not get the point and I am all too well aware that the point is subtle; instead she needs to be thanked for her offer and reassured that I will accept it-and then many pleasantries later perhaps we can discuss why we are at the lecture and whether we like it and what workshop we will attend that afternoon. When I complain of countless such incidents to most of my nondisabled friends and colleagues, I am told that I must understand how unusual it is to see a person with a disability in such a setting, that people are awkward, anxious, afraid of doing the wrong thing, only trying to be nice. My friends are right, and I will not get to know new people unless I tolerate these encounters and find ways to smile and be gracious and put people at ease.

But what of the people who have known me for years, who have considered themselves close friends but do not feel comfortable accepting my offers to pick

passengers that I must sit down, even though several other bus passengers were already standing on the crowded bus; I was pushed to the front of a line of customers at a bank, although blindness does not have any relationship to the ability to stand and wait one's turn in a bank line; I was spoken about rather than spoken to--"put her here" was said to a friend of mine as we walked into a crowded room to join a meeting; a friend was described by others not as my friend, but as my "assistant" and my "guide"; a friend of more than twenty years explained to me that my distress, irritation, and frustration were unreasonable responses to people who were "trying to do the right thing".

22 Charles R. Lawrence, III, The Id, the Ego, and Equal Protection: Reckoning with Unconscious Racism, in CRT: THE KEY WRITINGS, supra note 7 at 235-36. 
up food as part of a dinner we plan to have; or find themselves reluctant to have me join them when they are meeting new people because they see me as a social liability; or who would prefer that a high-school-age stranger take care of their six-year-old son for an evening than have me do it, even though I have known their son and their home ever since his birth? Making new acquaintances is difficult enough, but recognizing the limits that others' perceptions of blindness place upon important and long-standing friendships is far more painful and discouraging. The law can do nothing about the sorts of informal interactions described above that make up so much of the lives of people with disabilities lucky enough to have the education, jobs, and financial resources to be attending workshops and conferences, or taking vacations where they meet new people. In order for the ADA and other anti-discrimination laws to help people with disabilities truly enter the mainstream, judges and juries will need to learn far more than they typically know about how people with disabilities manage their lives. Anita Silvers is right when she asserts that the burden of proof is high for anyone with a disability who claims that it is not a tragedy to live with an impairment. ${ }^{23}$ However, it is more than that - the burden of proof is high to show that one can live competently at all.

\section{RIGHTS THEORY AND MODELS OF DISABILITY}

Despite the skepticism of much of CRT about the philosophy of liberal civil rights, and despite the conviction that racial minorities would gain only what dominant society would grant, ${ }^{24} \mathrm{CRT}$ departs from many friends in the movement of critical legal studies (CLS) in asserting the importance of rights language and rights laws. Mari Matsuda captures the CRT message well when she says:

How could anyone believe both of the following statements? (1) I have a right to participate equally in society with any other person; (2) Rights are whatever people in power say they are. One of the primary lessons CLS can learn from the experience of the bottom is that one can believe in both of those statements simultaneously, and that it may well be necessary to do so.

23 Anita Silvers, Formal Justice, in DISABIITY, DIFFERENCE, DISCRIMINATION: PERSPECTIVES ON JUSTICE IN BIOETHICS AND PUBLIC POLICY 13, 88 (Anita Silvets et al. eds., 1998).

${ }^{24}$ See the following reprinted essays by Derrick A. Bell, Jr.: Brown v. Board of Education and the Interest Convergence Dilemma, in CRT: THE KEY WRTINGS, supra note 7, at 20; Racial Realism, in CRT: THE KEY WRIINGS, supra note 7, at 302; and especially, The Civil Rights Chronicles: The Chronicle of the DeVine Gift, in CRT: THE CUTTING EDGE, supra note 6, at 390; as well as the introductory essays in each book discussing Bell's insights, and the review of Bell's book by Alan D. Freeman, Derrick Bell-Race and Class: The Dilemma of Liberal Reform, in CRT: THE CUTTING EDGE, supra note 6, at 458. 
$\ldots$

It is important to understand how claims to equality, procedural faimess, and political participation prove so compelling that human beings are willing to die for them ${ }^{25}$

The organizations and individuals considered part of "the disability rights movement" clearly endorse the importance of rights rhetoric and rights laws as essential to their struggle for equality and social participation. Denied access to vote, education, employment, housing, transportation, marriage and parenthood, many people with motor, sensory, cognitive, and emotional impairments-along with an impressive group of legal advocates-have spent decades fighting for legal safeguards to citizenship and social life. ${ }^{26}$ Using the rhetoric of other disenfranchised groups, disability activists and scholars began to describe their perspective as a "minority group model" of disability, as contrasted with the previously dominant medical views of having an impairment. According to the minority group view, the physical, cognitive, sensory, and emotional make-up of the individual was not "the problem," but was a problem only because social institutions and human-made environments were created without taking into account the characteristics of all people. 27 Without this bedrock conviction of the importance of legal rights as essential for any meaningful change in the position of people with disabilities, there would be not even the imperfect protections afforded by the patchwork of federal laws including the beleaguered and imperfect Americans with Disabilities Act. No matter how court decisions chip

25 Matsuda, supra note 12, at 66.

26 Typically, people speak of the disability rights movement as developing out of the civil rights movement and the women's movement, in the late 1960s and early 1970s, with the creation of the Center for Independent Living in Berkeley, California and the formation of Disabled in Action in New York City. See Joseph P. Shapiro, No PTTY: PeOPLE WTH DisABILTIES ForgING A NEW CIVIL RIGHTS MOVEMENT 53-58 (1994). However, some segments of the population of people with disabilities began asserting their claims to protection from discrimination decades before. See FLOYD W. MATSON, WALKING ALONE AND MARCHING TOGETHER: A HISTORY OF THE ORGANIZED BLIND MOVEMENT IN THE UNITED STATES, 1940-1990 (1990) (documenting the first fifty years of the National Federation of the Blind, as only one example of a single-disability group focused on acquiring rights to housing, travel, and employment); see also Jacobus tenBroek, The Right to Live in the World: The Disabled in the Law of Torts, 54 CAL. L. REV. 841 (1966).

${ }^{27}$ For some of the earliest such writings, see FRANK BOWE, HANDICAPPNG AMERICA: BARRIERS TO DisABLED PEOPLE (1978); FRANK BOWE, REHABIITATING AMERICA: TOWARD INDEPENDENCE FOR DISABLED AND ELDERLY PEOPLE (1980); GLIEDMAN \& ROTH, supra note

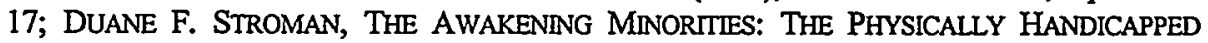
(1982); Harlan Hahn, Paternalism and Public Policy, SOC'Y, Mar.-Apr. 1983, at 36. For a more recent scholarly discussion that usefully compares and contrasts the strengths and limits of medical, economic, and minority group models of disability, see JEROME E. BICKENBACH, PHYSICAL DISABILITY AND SOCIAL POLICY (1993). 
away at its reach, and no matter how poorly federal agencies enforce its provisions, the law provides a tangible assertion that the federal government believes in the moral equality and worth of people with disabilities and believes that people can benefit from, and contribute to, the common life of the society.

Recent scholarship argues that the minority group model is inadequate to the task of affording people with disabilities the conditions to turn legal rights into realities. ${ }^{28}$ There are several reasons for replacing the minority group model with language that speaks of disability as a form of human variation and that calls for a universal design ${ }^{29}$ and universalizing of disability. First, impairments are multiple and various; the same impairment may affect several individuals differently, depending upon other factors in their environments and in their own lives. The same impairment may affect the same individual differently at different times in life. Second, making notions of impairment equivalent to forms of human variation would reduce the need to decide who is "in" and who is "out" of the group of people counted as people with disabilities, which has become one of the major methods of denying people protection under the employment provisions of the Americans with Disabilities Act. Third, people with various conditions have a range of needs that influence their ability to take advantage of legal entitlements to education, employment, or public services. Without income to meet certain impairment-related expenses such as medications, transportation, personal assistance services, particular diet supplements, or items of clothing, for

${ }^{28}$ Examples of calls for changing the conceptual framework include: Irving Kenneth Zola, Toward the Necessary Universalizing of a Disability Policy, 67 MIIBANK Q. 401 (1989); Jerome E. Bickenbach et al., Models of Disablement, Universalism and the International Classification of Impairments, Disabilities and Handicaps, 48 SOC. SCI. \& MED. 1173 (1999); Richard K. Scotch \& Kay Schriner, Disability as Human Variation: Implications for Policy, 549 ANNALS AM. ACAD. POL. \& SOC. SCI. 148 (1997); and Chai R. Feldblum, Definition of Disability Under Federal Anti-Discrimination Law: What Happened? Why? And What Can We Do About It? 22 BERKELEY J. EMP. \& LAB. L. 91 (2000). Although these writers stress different reasons, I need not differentiate their reasons.

${ }^{29}$ ADAPT!IVE ENVIRONMENTS CTR., INC., UNIVERSAL DESIGN at http://www.adaptenv.org/ universal/default.asp (last visited Feb. 27, 2001):

Universal design is a worldwide movement based on the concept that all products, environments and communications should be designed to consider the needs of the widest possible array of users. It is also known around the world as design for all, inclusive design, lifespan design. Universal design is a way of thinking about design that is based on the following premises:

- Varying ability is not a special condition of the few but a common characteristic of being human and we change physically and intellectually throughout our lives;

- If a design works well for people with disabilities, it works better for everyone;

- At any point in our lives, personal self-esteem, identity, and well-being are deeply affected by our ability to function in our physical surroundings with a sense of comfort, independence and control. (Leslie Kanes Weisman, 4/99);

- Usability and aesthetics are mutually compatible. 
example, individuals may not flourish. Without the assistance of job coaches or other support staff, persons with emotional or cognitive impairments may not receive the individual assistance that permits them to manage the demands of typical schools or jobs. Without equipment or work schedules adjusted for rest or medical appointments, people with limited energy or with chronic pain may be unable to perform work for which they are otherwise well suited.

Scotch and Schriner argue:

[T] he minority group model cannot serve as the sole underpinning for disability policy.... [T] he commonly held notion of discrimination must be so stretched to include the various barriers faced by people with disabilities that the concept loses some of its precision and thus its utility as a guide to policy. It may be more useful ... to look beyond discrimination to characterize the nature and consequences of a constructed environment that ignores the presence of people with disabilities

....

... [D]isability thus may be seen as an extension of the natural physical, social, and cultural variability of the human species. Disability could be defined as an extension of the variability in physical and mental attributes beyond the present-but not the potential-ability of social institutions to routinely respond.

In this ... human variation model of disability, the problems faced by people with disability might be seen as the consequence of the failure of social institutions (and their physical and cultural manifestations) that can be attributed to the institutions' having been constructed to deal with a narrower range of variation than is in fact present in any given population. 30

Perhaps they are right in arguing that the concept of discrimination is "stretched" when it must incorporate concepts of "reasonable accommodation" in employment, or when such barriers as narrow doors have barred access to a service, lack of telephone relay systems, or needlessly inflexible work schedules. However, I want to argue that absent the pernicious belief that people with disabilities do not contribute to social or economic life and actually drain social resources, there would have been far more willingness prior to legislation to modify the social and built environment to include all the citizenry. I think that a "human variation" model has many advantages for people with a range of impairments, as I will discuss below, because it removes some of the pejorative "specialness" and "exceptionality"-some of the "us and them" quality-from disability and reminds everyone that human beings come in a variety of physical, mental and emotional make-ups that change over time and may fit well into some sizes of clothing and some environments, but not others unless we make more metaphorical and literal clothing sizes, styles of furniture, and methods of

${ }^{30}$ Scotch \& Schriner, supra note 28 , at $152,154-55$. 
providing information to accommodate the range of physical, perceptual, and cognitive equipment that human beings possess.

What Matsuda, Bell, and other CRT writers contend, which I must concede, is that society will balk at making modifications that include everyone unless dominant members of that society can be perceived to benefit as a by-product of these changes. How often, for example, are the proliferation of curb cuts, ramped entrances, and widened doorways hailed as a benefit for people who push shopping carts, or for parents wheeling baby strollers! I applaud the fact that nondisabled persons may discover the convenience of these architectural changes, but they should not be justified as worthwhile because nondisabled people can enjoy them. They are worthwhile even if no substantial benefit accrues to the shopper or the parent and child using the stroller-which is, after all, an assistive device for young children to be mobile in the world-simply because they do benefit a portion of the population otherwise disenfranchised from our streets and public facilities.

In a small, but chilling example of societal resistance to complying with the legal requirements of providing access to mass transit to people with reading disabilities, the manufacturer of new technology told the following story to a convention of 2,500 members of the National Federation of the Blind: a device has been developed that, when installed on city buses, will verbally announce each stop, a great boon to anyone whose vision prevents the reading of street signs. ${ }^{31}$ According to the regulations developed to implement existing law, bus drivers are expected to announce the stops, even without the device, but the device was developed because of well-known reluctance to do so and noncompliance with the law. However, the manufacturer of this technology revealed to the assembled convention-goers from every state in the nation that not even the installation of this technology was solving the problem of assuring that blind passengers could know where they were; bus drivers were turning off the device because they did not like having it as a routine part of their day. ${ }^{32}$

Exactly what prevents the drivers from calling out the stops themselves or from using the device developed and bought to get around their reluctance? Is it that they actually resent having non-reading passengers on the bus? Is it that the sound is more intrusive and monotonous than the same street signs? Is it that the environmental accommodation, the street sign usable by the visual reader, is considered ordinary, but the means that benefits the smaller number of passengers with visual, perceptual, or cognitive impairments is considered

31 Prior to this invention, of course, visually impaired and blind travelers solved this problem by asking the bus driver to announce the stops or asking fellow passengers, if they did not memorize the routes and know the stops from frequent use.

32 Bill Long, Smart Buses: Solving the Problem of Calling Bus Stops Address, at the 60th Convention of the National Federation of the Blind (July 7, 2000). 
extraordinary, "special," foolish, or wasteful? Should such people not ride the public bus and use even more expensive segregated transit, or remain under constant supervision at even more expense, or simply not be abroad in the land? Will recalcitrant bus drivers call out the stops or at least tolerate the computerized announcements only when they are threatened with job loss, or when "ordinary," nondisabled passengers tell them that they find the announcements convenient so that they need not continually look up from their newspapers, or so they can be roused from dozing during a long ride?

Hearing this story, some people had the eerie feeling that perhaps Peter Singer, the bioethicist who believes that parents should be able to end the lives of "severely" impaired newborns if they do not want to raise them, might be right. ${ }^{33}$ Perhaps the world really just does not want people with disabilities to be around after all. Until it is legitimate, respectable, and acceptable to be a person with a disability in the world, until the nondisabled majority recognizes how ubiquitous impairment is and how likely it is that everyone will experience it themselves or in someone they love, and until the nondisabled majority perceives that the millions of people with impairments are fully human and can contribute in meaningful ways to the economy and the family, that world will fight against every legal or moral claim made upon it to change institutions, cultural practices, and institutional and physical structures to become readily inclusive. Disability policy and politics must speak to the economic and emotional needs of the nondisabled majority to convince them that the accommodations made for people with disabilities in many ways can benefit them, if not directly, then indirectly. They must be persuaded that they, too, are accommodated in all manner of ways by social and architectural structures. As Susan Daniels, former Social Security Commissioner for Disability is fond of pointing out, only those conferees using wheelchairs "bring their own chairs"; lights, microphones, and loudspeakers are environmental accommodations for those who obtain sensory input by sight or hearing. ${ }^{34}$ Only when something like the Scotch and Schriner model of disability as human variation becomes widespread will it be possible for the majority to recognize that what they expect and demand as ordinary parts of institutional and physical life is no more required or reasonable than the changes that might make it possible for people with impairments to participate in routine activities.

33 PeTER Singer, PRACTICAL ETHICs 184 (2nd ed. 1993). ("[T] he main point is clear: killing a disabled infant is not morally equivalent to killing a person. Very often it is not wrong at all.") Id. at 191. Peter Singer has reiterated his views in two public presentations in 1999: Address at Princeton University (Oct. 12, 1999), and Address at the 2nd Annual Meeting of the American Society for Bioethics and Humanities (Oct. 29, 1999).

${ }^{34}$ Susan Daniels, Address at the Conference of the Association for Higher Education and Disability (July 14, 1999). 


\section{ARE ALL IMPAIRMENTS CREATED EQUAL? IMPLICATIONS OF THE VARIETY OF IMPAIRMENTS}

Unfortunately, the very attempt to define a class of people called "disabled" under the Americans with Disabilities Act, and to indicate which members of the population could claim its protections, runs counter to the laudable goals of including people who have been disenfranchised by societal practices. Remember that the statutory definition of which persons can claim coverage under the Act as persons with disabilities defines a qualified individual in three ways: "(A) a physical or mental impairment that substantially limits one or more of the major life activities of such individual; (B) a record of such an impairment; or (C) being regarded as having such an impairment." 35 It thus differentiates between those who have "objective" departures from species-typicality, or what some people might consider "the truly disabled," and those who are inaccurately perceives as impaired by virtue of a record or of a misclassification. For purposes of medical care and certain rehabilitative services it is important to understand the nature of the departure from species-typicality to provide the correct medication or rehabilitation; for example, people with mobility impairments do not need Braille and people who are blind do not need wheelchairs. For purposes of combating discrimination and unequal treatment that is the purpose of the Americans with Disabilities Act, there is no need to differentiate between the truly disabled and those merely "regarded as" disabled to determine whether there has been unlawful treatment by an employer, a restaurant, or a government agency.

Let me put forward the following, possibly radical, proposal: Instead of discussing which kinds of people have impairments or disabilities and which people do not, instead of saying that some members of society are disabled and others are not, we should consider which people cannot perform which activities in given environments and question how to modify the environments so that they are not disabling. Arguably, any person now living could, without any change in his or her physical, cognitive, sensory, and emotional make-up, be considered impaired by some employer, government service provider, place of public accommodation, or educational institution if the individual failed to meet particular standards for acceptance into a program or activity that the organization had established. Instead of discussing impaired individuals, attention should go to determining which environments-which social, physical, bureaucratic, and communication structures-could incorporate the widest array of individuals in all their diversity of capacities and then determine which environments were impairing and how they could be modified. When individuals complained that they were barred from an activity, program, or job because they

3542 U.S.C. §§ 12101-12213 (1994). 
were deemed outside the range of people the organization could accommodate, society could then decide on a case-by-case basis whether it wished the environment to change or wished to permit the exclusion of individuals because the environment found their characteristics unacceptable. Arguably, the most important prong of any definition of disability is that of being "regarded as" being impaired. Until society moves to evaluating the inclusiveness of environments, and as long as it insists upon evaluating which members of the population can fit into the existing ones, it would be better to recognize that all claimants under the ADA should be evaluated as having been "regarded as" impaired by the employer or other institution against which they are filing a complaint.

Readers may ask whether, on a "human variation" approach to disability, anyone might, at some point in life, believe that she or he should be able to use the Americans with Disabilities Act to claim a benefit, service, or job that they believed had been unfairly denied to them. Was the Americans with Disabilities Act intended for a particular "group" of people, or should it have been? Both disability rights advocates and ADA detractors have noted that many of the employment discrimination cases filed since the enactment of the ADA have not been brought by people commonly thought of as having disabilities, typically persons with visible impairments. In his preface to a group of articles devoted to the Americans with Disabilities Act, economist William Johnson writes:

The ADA was clearly intended to provide entitlements to the persons represented by the advocacy groups, and little attention was given to the large number of persons who are identified as part of the disabled community by national surveys.

....

... Information presented... demonstrates that the suits filed under the provisions of the $\mathrm{ADA}$ are more likely to come from the larger population than from the target group envisioned by the ADA's supporters. The larger group consists of persons, typically middle-aged or older, with nonvisible impairments, such as arthritis, cardiovascular conditions or chronic back pain that first occurred during adulthood. ${ }^{36}$

People familiar with cases filed under state and federal disability discrimination laws that existed prior to the enactment of the ADA should not have been surprised, since large numbers of state and federal cases of disability discrimination in employment had been brought by just such members of the population of those with disabilities. ${ }^{37}$

36 William G. Johnson, Preface, 549 ANNALS AM. ACAD. POL. \& SOC. SCI. 8, 8 (1997).

${ }^{37}$ Nancy R. Mudrick \& Adrienne Asch, Investigation and Enforcement of a Disability Discrimination Statue: Complaints of Employment Discrimination Filed in New York State, 7 J. DISABILITY POL'Y STUD. 21, 27 (1996). 
I do not believe that this finding should trouble either disability rights advocates or give ADA detractors cause to contend that the law is being misused or being invoked to solve trivial problems. My non-lawyerly conviction accords with my understanding of ADA expert Chai Feldblum's discussion of the problems of definition in which the courts are now embroiled. ${ }^{38}$ Instead of concluding that a person who uses eyeglasses or blood pressure medication is not a person with a disability for purposes of the Americans with Disabilities Act, it would be much more in keeping with the human variation approach to disability discussed above, and with the philosophy of non-discrimination embodied in Griggs v. Duke Power Co., 39 to permit such people to file complaints of employment discrimination as people who are "regarded as" having an impairment. The employer would then bear the burden of proving that the employee cannot, in fact, perform the essential functions of the job and that the employer's medical standards are job-related. Permitting more people to claim protection from discrimination does not imply that their claims are correct, or that they can perform the essential functions of a particular job; nor does it suggest that employers are wrong in arguing that "reasonable accommodations" that might be needed by some people with certain conditions would impose an "undue hardship." 40 Such an approach simply calls for employers to ascertain which purported job requirements are truly necessary and which are the results of custom or convenience.

Along with other contemporary theorists of disability and of race, I conclude that what constitutes an impairment or disability, as what constitutes a racial category, is socially constructed. ${ }^{41}$ Such a statement is not news; but law, society, and philosophy of race, sex, or disability are still working out the implications of

${ }^{38}$ See Feldblum, supra note 28.

39401 U.S. 424 (1971).

${ }^{40} \mathrm{I}$ recognize that persons filing complaints alleging that employers regard them as impaired when they believe they are not impaired will not be claiming a need for employerprovided "reasonable accommodation." They may be claiming that the glasses they wear or the medications they take to control blood pressure are their accommodations to their physical characteristics, but that employers believe those employee-provided accommodations are inadequate or ineffective measures for successful job performance.

If the nation adopted the "regard as" formulation of disability I suggest and analyzed whether a person had been "regarded as" disabled because of an inability to perform in an existing environment, it would then have to recognize that the "reasonable accommodations" employers may be asked to pay for are necessary only because the existing environment does not permit all potential employees to function effectively. It is an accommodation to the interactions of their biology with the existing, hitherto unaccommodating and impairing environment.

${ }^{41}$ Ian F. Haney López addresses the social construction of racial categories in The Social Construction of Race, in CRT: THE CUTTING EDGE, supra note 6, at 191, and White by Law, in CRT: THE CUTTING EDGE, supra note 6, at 542. 
the idea that formerly given categories are socially constructed. Saying that disability is socially constructed does not imply that the characteristics are not real or do not have describable effects on physiological or cognitive functions that persist in many environments. Just as the medical responses to different conditions are not identical, the social construction approach to disability does not imply that the social/psychological/non-medical consequences of arthritis, muscular dystrophy, Down syndrome, hypertension, attention deficit disorder, or back pain are identical, or that the accommodations, services, and responses to each condition need be identical.

Such factors as how observable an impairment is, what physical, sensory, or cognitive/emotional functions are affected, whether it is static or progressive, whether it is predictable or unpredictable in its manifestations, and whether it affects longevity, all may influence the experience of disability for the person who has the condition, as well as for those around such an individual. 42 In different circumstances, the visibility of a characteristic - be it femaleness, weight, hair color, skin color, or navigating in a wheelchair-may influence someone's experiences. Persons with characteristics such as diabetes or asthma that may not be readily observable may sometimes find that their impairments affect a given set of activities and life decisions, whereas at other times they find life flowing smoothly with no thought to their medical label. Although appearing nondisabled when one first meets people professionally or socially may permit the person with diabetes or asthma to avoid the often adverse reactions of others to observable orthopedic, visual, or speech impairments, these so-called hidden disabilities may influence social life such as the food one eats, the places one visits, the activities one pursues for recreation, and so forth. Fearing the adverse reactions of others to the disclosure of a characteristic like diabetes, asthma, treated cancer in remission, a heart condition, or a history of mental illness

42 Not all of these factors have been systematically explored to determine which factors are more important at different times, or whether there is a pattern of responses that makes shortened lifespan more disturbing, for example, than visibility, either to people who live with the conditions themselves or to their associates. For discussions of attitudes toward people with disabilities, see generally, ATTITUDES TOWARD PERSONS WTH DISABILTIES (Harold E. Yuket ed., 1988); RICHARD F. ANTONAK \& HANOCH LIVNEH, THE MEASUREMENT OF ATTITUDES TOWARD PEOPLE WITH DISABILIrIES (1988); Elaine Makas, Positive Attitudes toward Disabled People: Disabled and Nondisabled Persons' Perspectives, 44 J. SOC. IssuES 49 (1988). For discussions of the psychological impact of disability upon individuals and families, see JoHN S. ROLLAND, FAMIIIES, ILLNESS, AND DISABILITY: AN INTEGRATIVE TREATMENT MODEL (1994); Rosalyn Benjamin Darling, Parental Entrepreneurship: A Consumerist Response to Professional Dominance, 44 J. SOC. IssuES 141 (1988); Philip M. Ferguson et al., The Experience of Disability in Families: A Synthesis of Research and Parent Narratives, in PRENATAL TESTING AND DISABILITY RIGHTS 72 (Erik Parens \& Adrienne Asch eds., 2000). For classic material on living as a person with a disability, see BEATRICE A. WRIGHT, PHYSICAL DISABLITY-A PSYCHOSOCIAL APPROACH (2d ed. 1983). 
produces its own psychological consequences; the stress of hiding may turn out to be as problematic as the feared responses from disclosure. A mother or father might be deeply shaken by learning that a child with cystic fibrosis could die in their thirties but might react with much less concern upon discovering that a child could expect an average lifespan but would have cerebral palsy. A different set of parents, on the other hand, might find the relative invisibility of a child's cystic fibrosis easier to incorporate into their lives than the more easily perceived, and thus possibly more stigmatized, condition of cerebral palsy.

My point here is that impairments impinge upon people differently from one another depending upon a host of psychological and social factors that all are external to the biomedical condition. Disability theorist Harlan Hahn characterizes disability as eliciting "existential and aesthetic anxiety" in others. ${ }^{43}$ Notable in the history of governmental discrimination and segregation documented in the Garrett case is that people with only certain conditions received some of the most isolating and demeaning treatment. ${ }^{44}$ The medical model of disability would explain this fact by contending that people with substantial departures from a notion of "species-typical" cognitive, orthopedic, hearing, and visual norms may be the only ones with genuine impairments. But from a social constructionist view, it is only that their characteristics were considered more difficult to incorporate into more environments. People who had such characteristics as ulcers, high blood pressure, or bad backs were more easily incorporated. As environments routinely incorporate members of society. with historically stigmatized labels, the characteristics themselves could become as unremarkable as brown eyes or long hair. There is one such striking example on Martha's Vineyard in Massachusetts in the nineteenth century, as documented by Nora Groce in her book, Everyone Here Spoke Sign Language, in which she explained how common hereditary deafness ceased to be a disability because all island residents routinely used both sign language and speech for communication. 45

Are there some environments that we do not wish to modify to admit a broader range of persons than now function within them? Should the rules of golf be modified to permit Casey Martin to use a cart to travel around the course, ${ }^{46}$ or do we wish to maintain that playing golf requires a particular complement of physical capacities? We can choose. Can air carriers continue to have vision

43 Harlan Hahn, The Politics of Physical Differences: Disability and Discrimination, $44 \mathrm{~J}$. SOC. ISSUES 39, 39 (1988).

44 Brief of Amici Curiae, supra note 4.

45 NORA E. GROCE, EVERYONE HERE SPOKE Sign LANGUAGE: HEREDITARY DEAFNESS ONMARTHA'S VINEYARD (1985).

46 See PGA Tour, Inc. v. Martin, 204 F.3d 994 (9th Cir. 2000), cert. granted, 121 S. Ct. 30 (Sept. 26, 2000) (No. 00-24). 
standards for pilots that preclude the wearing of glasses as the method of seeing the instruments? Reasonable people and experts on piloting and air safety may disagree among themselves about which physical, sensory, and cognitive abilities are crucial for successful control and navigation of an aircraft, but the debate about Sutton v. United Air Lines, Inc. ${ }^{47}$ should have been on the grounds of business necessity, on essential functions of a demanding job, and not on the level of a particular person's impairment in some objective sense, abstracted from the circumstance in which capacity was at issue. Similarly, the Department of Transportation medical standard for truck drivers should be at issue in Murphy v. U.P.S., 48 and not whether the individual had an impairment that prevented him from engaging in a substantial life activity. He was outside the environment that had been established for the job he sought; the relevance of the standard to the job, not his blood pressure in an abstract sense, should have been evaluated.

In these recent employment decisions, I decry the philosophy behind courts declaring that people are not sufficiently impaired to claim the statute's protection. Employers may successfully persuade courts to conclude that environments should not be more flexible with regard to a particular individual's characteristics. However, in the instance where an individual is denied a position because of measured blood pressure, for example, the employer should be asked to show why blood pressure of a certain reading disqualifies someone from performing the essential functions of a job, and should not be able to argue that someone with blood pressure of a measured reading is not a person with an impairment under the meaning of the statute. Since the individual is alleging that employment was denied based on the blood pressure, the employer should be required to indicate either that the allegation is false or that it is true and that there is a legitimate, nondiscriminatory reason based on the requirements of the job. 49

Are environments infinitely flexible? Each time environmental arrangements are challenged, society, as represented by courts and legislatures, must decide how flexible and inclusive it will be. To those unacquainted with how people with such characteristics as quadriplegia, autism, or limited ability to use or

${ }^{47}$ Sutton v. United Air Lines, Inc., 527 U.S. 471 (1999).

48 Murphy v. United Parcel Serv., Inc., 527 U.S. 516 (1999).

49 Although I have not litigated or investigated cases filed under the Americans with Disabilities Act, I base the comments in the foregoing section partly on my years of work dealing with cases of employer-devised medical standards under the New York State Human Rights Law. From 1974 to 1977 and then from 1980 to 1985, I worked with the New York State Division of Human Rights in several professional capacities, examining the legitimacy of employers' vision, blood pressure, and other medical requirements as they applied to positions of truck driver, nurse, lifeguard, and other positions. New York's Human Rights law contained no "reasonable accommodation" provision, yet that law was successfully used by complainants to show that many employer medical standards were, in fact, not job-related. 
understand verbal language would study, work, or care for children, it may seem impossible; but people with such characteristics are now succeeding in these activities because they have found or constructed arrangements in which they can contribute based on their capacities and receive assistance with facets of life that are difficult. Arguably, that is what everyone does in life. Most lawyers do not repair their automobiles, but society does not degrade them for being "dependent" upon mechanics. There is no reason to devalue, patronize, or question the legitimacy of someone who obtains spoken information via an interpreter or real-time captioner, or who gets ready for work with the assistance of another human being who prepares meals or puts on clothes. Similarly, the man with limited verbal language who works with support staff to run errands, and who invites others to his home for holidays, conducts customary adult activities of work, being a member of a household, and maintaining a social life. In these environments he is not a person with a disability. If few environments will accommodate his mix of talents and needs, the problem may be the lack of imagination or the lack of will on the part of others.

If people labeled as mentally ill are filing complaints of discrimination in employment, it may derive from the existential anxiety occasioned by contact with someone whose behavior may be feared unpredictable, out of their or our control, or whose modes of social interaction startle those with the power to make employment decisions. Perhaps the difficulty they experience in finding employment should be attributed to managerial resistance to incorporating a person with particular characteristics into a fixed environment. People now thought unemployable in one setting may be employable in another setting that adapts to a greater level of human variation. If the social norm becomes one of trying to achieve an adaptive environment that can easily respond to a broad range of talents and needs, then we may be able to accept the occasional institution or setting with fixed standards of performance. Acting on Broadway may legitimately require more experience, skill, and versatility on the part of those who audition than acting in the community theater. Banks, restaurants, and the Internet should be open to all, accessible to and usable by virtually anyone. Most educational and employment situations should fall somewhere between the bank and the Broadway audition, and denials of employment should be based on an individualized assessment of why a particular applicant or employee was unsuitable for a particular job. Fluency with verbal and written language, for example, might be a skill basic to many positions in the contemporary economy. Anyone, who for any reason could not understand or express herself in words in any way would have limited work options; but employers who turned away people who could not communicate fluently should be able to demonstrate why this skill was required for the particular position, and not resort to the statement that "all employees must be able to read and write and communicate at a sixth grade level." 
I started the section by asking whether all impairments were equal and then proposed that instead of speaking of impairments at all, we should be speaking of environments. In noting that only some people who departed from the physical, sensory, cognitive, and emotional norms historically were subject to the most virulent forms of segregation, isolation, and neglect, I am acknowledging that historically and in contemporary society, the different forms of human variation called disabilities draw different responses. Children and youth with cystic fibrosis or diabetes, for example, are not typically isolated from others in their same grade in rooms for the disabled, but children with other characteristics deemed more challenging for the typical environment are still often educated in separate spaces. When they complete their education, those with cystic fibrosis or diabetes are likely to have an easier time finding work than someone with manual, but not linguistic or mathematical, skill. People who do not stand out by appearance or speech occasion no "aesthetic anxiety" in restaurants and movie theaters, and if they hide the fact of their epilepsy or back pain from others, they may go through much of their life without triggering the existential anxiety Hahn describes as an explanation for the discriminatory treatment that the $\mathrm{ADA}$ is designed to combat. Within the large group of people who may not fit into existing environments and social arrangements, some have been and may continue to be considered more challenging to existing arrangements than others. But if we take the human variation model seriously, we should be questioning the arrangements for failing to include, rather than assuming that the arrangements are fine as they are and concluding that it is the personal deficiency that prevents certain people from participating.

\section{INTEGRATION AS A GOAL?}

In discussing the justifications for ending de jure and de facto segregation based on race, commentators from within critical race theory point out that implicit in the championing of "integration" was the idea that Black-White contact was good for Blacks because White-controlled institutions were selfevidently superior to those in the Black community..$^{50}$ Quoting Malcolm X, Peller points out that segregation and separation are not identical, and that selfchosen separation sometimes can be necessary and valuable.

A segregated school system isn't necessarily the same situation that exists in an allwhite neighborhood. A school system in an all-white neighborhood is not a segregated school system. The only time it's segregated is when it is in a community other than white, but at the same time is controlled by whites. So my understanding of

${ }^{50}$ Peller, supra note 9. 
a segregated school system- or a segregated community, or a segregated school-is a school that's controlled by people other than those who go there. ${ }^{51}$

Going on, Peller contrasts his own view with his description of the convictions of integrationists, who say that "race makes no real difference between people, except as unfortunate historical vestiges of irrational discrimination." 52

Peller makes a powerful argument for the value of community-controlled, strong institutions within the particular community. He argues that the goal of integration can never be truly achieved, or that if it could, it would not be desirable for it would be a "total absorption and disappearance of the race-a sort of painless genocide."53 Peller contrasts his own view with his understanding of a reigning 1960s liberal ideology "that race could be understood as just another example of the range of arbitrary social characteristics-like gender, physical handicap, or sexual preference-that rightthinking people should learn to ignore." 54

He concludes his challenge to integrationist ideology:

[T] he construction of race reform as overcoming bias at the level of consciousness, overcoming discrimination at the practice level, and achieving integration at the institutional level has meant that tremendous social resources and personal energy have been expended on integrating formerly white schools, workplaces, neighborhoods, and attitudes. This program, ... has had some success in improving the lives of specific people and in transforming the climate of overt racial domination.... Yet it has been pursued to the exclusion of a commitment to the vitality of the black community as a whole and to the economic and cultural health of black neighborhoods, schools, economic enterprises, and individuals. ${ }^{55}$

How does this apply to the situation of people with disabilities, or to what is described as "the disability rights movement" or "the disabled community"? Most people who have disabilities acquire them in mid-life and struggle to incorporate their changed bodies and minds into pre-existing work and family arrangements. Even for those who acquire their conditions at birth or in childhood and young adulthood, most characteristics are not genetically transmitted, and thus, only a small fraction of the millions of people with disabilities grow up in a natural community of others with their same characteristic.

\footnotetext{
51 Id. at 128.

52 Id. at 130.

$53 \mathrm{Id}$. at 135 .

54 Id. at 150.

$55 \mathrm{Id}$. at 151 .
} 
Lack of natural community, the variability among impairments and the domination of medical services and philanthropic disability service organizations by nondisabled professionals have all mitigated against developing a strong, coherent, politically powerful community of people with disabilities. Nonetheless, these same people were kept out of schools and classes, workplaces, and sometimes neighborhoods and social life with nondisabled people of their age, sex, or ethnicity. If community formed at all among those with disabilities, it generally occurred along single-impairment lines, through residential schools for people who were deaf or blind, in institutions for people with intellectual or psychiatric diagnoses, or in the wards of rehabilitation centers. $^{56}$

Here, many allies among the ranks of disability scholars may not share some of my views, perhaps because I formed my views of disability politics out of the very White integrationist views of the sixties. ${ }^{57}$ Like others, I wholeheartedly endorse the integrationist, inclusionist philosophy behind IDEA, ${ }^{58}$ the Olmsted $v$. L.C. decision, ${ }^{59}$ and the fight to keep people who need personal assistance services in their own families and neighborhoods and out of institutions or nursing homes. Voluntary associations for political or social purposes, controlled by people with disabilities, play crucial roles for many people and have championed the federal and state legislation that symbolizes acceptance into the nation's social and economic life. Deaf culturists, some members of the National Federation of the Blind, and some disability scholars, fed up with the social isolation and inadequate academic preparation of disabled students educated in the public schools since the passage of P.L. 94-142 in 1975, echo the views of Gary Peller and Malcolm X and call for a re-creation of separate schools that would give disabled youth strong academic skills, a life with potential friends, and a chance to develop ties to others with disabilities. Rather than support even a disability-controlled, disability-affirmative school, I urge our leaders and

${ }^{56}$ For a discussion of the cites of and barriers to self-organization among people with disabilities, see generally RICHARD K. SCOTCH, FROM GOOD WIL TO CIVIL RIGHTS: TRANSFORMING FEDERAL DISABIITY POLICY (1984); Richard K. Scotch, Disability as the Basis for a Social Movement: Advocacy and the Politics of Definition, 44 J. Soc. Issues 159 (1988).

57 I write about a part of my own development in Adrienne Asch, Personal Reflections, 39 AM. PSYCHOLOGIST 551 (1984); and in Philip M. Ferguson \& Adrienne Asch, Lessons from Life: Personal and Parental Perspectives on School, Childhood, and Disability, in SCHOOLNG AND DISABILITY 108 (Douglas Biklen et al. eds., 1989).

58 Individuals with Disabilities in Education Act, 20 U.S.C. $§ 1415$ (1994).

59 Olmstead v. L.C., 527 U.S. 581 (1999) (holding that the ADA requires states to provide community-based treatment for individuals with mental disabilities when treatment professionals determine that the placement is appropriate, the treatment is not opposed by the affected parties, and placement can be reasonably accommodated). 
scholars to put our energies into promoting high expectations for the academic and social development of disabled youth in neighborhood schools. Genuine inclusion in schools along with nondisabled age-peers cannot come without environmental changes. Teachers must not refuse to give the schedule to a band member in a form she can read and thus reject her from the band because she can play the flute but cannot read the printed schedule..$^{60}$ As a first grade student, Amy Rowley was denied interpreter services in her classroom of hearing, nonsigning students and teachers because she was reported to be passing from grade to grade despite her inability to obtain the same information as her classmates. She is now in her twenties, but the Supreme Court decision denying her the interpreter service has never been revisited. ${ }^{61}$

No wonder that Deaf community members would prefer to see today's deaf students be taught by people who could use American Sign Language and have classmates with whom they could communicate. Similarly, there is reason to fear that a classroom aide who functions as sole teacher and social contact, leaving the student isolated from the designated teacher and the other students is segregating students with a range of disabilities within the public school and classroom. ${ }^{62}$

The same need to form political action groups or support-groups that has fueled organizations like the National Federation of the Blind, Little People of America, People First, Disabled in Action, the Disability Rights Education and Defense Fund, and more may continue for many years and probably should include increased attention to disabled youth, much as churches and synagogues organize youth groups for their members. Until a teenager with cerebral palsy receives the message from his teachers, peers, and family that he should set his future goals based on interests and talents, and not ask himself "What can a boy with cerebral palsy do?" he is likely to need contact with older people with similarly atypical motor or speaking skills to assure him that there is a future. But these contacts, built around life with disability, should not be offered as his principal source of companionship, with the implication that he cannot expect equal-status friendship from among nondisabled members of his own school or class.

${ }^{60}$ The mother of a seventh-grade girl who is blind reported this story to me on September $23,2000$.

${ }^{61}$ Bd. of Educ. v. Rowley, 458 U.S. 176 (1982).

62 For well-worked-out discussions of exemplary programs that incorporate a wide range of students thought "too disabled" to be in the public schools, see GAll MCGREGOR \& R. TIMM VOGELSBERG, INCLUSIVE SCHOOLING PRACTICES: PEDAGOGICAL AND RESEARCH FOUNDATIONS: A SYNTHESIS OF THE LITERATURE THAT INFORMS BEST PRACTICES ABOUT INCLUSIVE SCHOOLNG (1998); and Dorothy K. Lipsky \& Alan Gartner, Taking Inclusion into the Future, EDUC. LEADERSHP, Oct. 1998, at 78. 


\section{RACE-CONSCIOUSNESS, DISABILITY-CONSCIOUSNESS, AND IDENTITY POLITICS}

While my dedication to the goal of social integration is tempered by my conviction that oppressed people, including those with impairments, will need to combat their situation by maintaining groups for social support and political action, the same dedication to the goal of integration leads me to hold each of the following views described respectively by Randall Kennedy, a professor who is African-American, and Duncan Kennedy, a professor who is a White critical race theorist. Randall Kennedy has stated:

I simply do not want race-conscious decision-making to be naturalized into our general pattern of academic evaluation. I do not want race-conscious decision-making to lose its status as a deviant mode of judging people or the work they produce. I do not want race-conscious decision-making to be assimilated into our conception of meritocracy. 63

Taking issue with the world as ready for the meritocracy without reference to race that Randall Kennedy advocates, Duncan Kennedy responds:

One index of a community's cultural subordination is its dependence on others to produce knowledge in areas where it would seem, at least superficially, that community interests will be affected by what that knowledge is.

... Along with more scholarship on minority issues, there should be more scholarship on the implications for minorities of any issue currently under debate. In other words, Hispanic scholars working on the purest of corporate law questions within the most unquestionably Anglo scholarly paradigm are still, I think, more likely than white scholars to devote, over the long run, some time to thinking about the implications of law in their chosen technical area for the Hispanic communities. ${ }^{64}$

The two statements appear incompatible, yet I endorse both. In a society that still makes race, or sex, or sexual preference, or health status a basis for differential treatment in matters of life where the factor is irrelevant to the activity, members of "out" groups continue to share experiences Iris Young describes as five "faces" of oppression: exploitation, marginalization, powerlessness, cultural imperialism, and violence. ${ }^{65}$ Absent family lineage or geographic concentration in neighborhoods outside of schools or treatment

63 Duncan Kennedy, A Cultural Pluralist Case for Affirmative Action in Legal Academia, in CRT: THE KEY WRITNGS, supra note 7, at 159, 162 (expressing statements made by Randall Kennedy).

64 Id. at $167-68$.

65 IRIS MARION YOUNG, JUSTICE AND THE POLITICS OF DIFFERENCE 40 (1990). 
centers, disabled people with experiences of oppression have formed social and political organizations based on their shared experience-largely of being patronized, dismissed, misunderstood, in short, mistreated.

Do people with disabilities share positive experiences or see themselves as members of a cultural community with traditions to pass on and wisdom to teach? Many people in the Deaf community point to theater and poetry performed through ASL as examples of the richness of their cultural life. ${ }^{66}$ Some longtime movement activists are bound together not only by their friendships and histories of political victories and defeats, but by the time spent in making disability politics the emotional centerpiece of their lives, much as any members of political movement groups or other causes might describe their passionate commitment as at the center of their lives and their psychological orienting point in the world. ${ }^{67}$ How much is disability part of identity for members of the movement, or for people who are not part of it? Whenever people with disabilities are surveyed by the Louis Harris organization, as they have been frequently since 1986, it turns out that pluralities, sometimes majorities, of respondents perceive disability status as akin to minority status and feel some commonality with people who have the same, or different impairments. 68 Carol Gill, disability scholar and researcher on disability and identity, argues that in order for people with disabilities to function well in this oppressive society, disability should be a "positive and central" part of their identity. ${ }^{69}$ Philosophers Anthony Appiah and Anna Stubblefield each have written valuable articles considering what it would mean to say that "race" or "sex" were a central component of identity. Appiah, for example, says that he could still be himself,

${ }^{66}$ I recognize that members of the Deaf community join together based on a shared language, ASL, that gives them a status of both a linguistic and a disability community. Even the statement of including Deaf people as members of the disability community is controversial, since many reject the label of disability when it is applied to them. However, since people who are Deaf, as well as deaf people who do not identify with the Deaf cultural world, avail themselves of the provisions of the Americans with Disabilities Act in order to obtain telephone relay services and the right to ASL interpreters or real-time captioners, I believe it is not inappropriate to consider them, for some purposes, members of the large population of people impaired in environments without provisions for communicating in a means other than spoken language.

${ }^{67}$ For discussions of "disability culture," see Mary Johnson, Emotion and Pride: The Search for a Disability Culture, DISABLITY RAG, Jan./Feb. 1987, at 7; Paul K. Longmore, The Second Phase: From Disability Rights to Disability Culture, 16 DISABILITY RAG, Sept/Oct. 1995, at 4; and VITAL Signs: CRIP CUltuRE TALKS BACK (Brace Yourself Productions 1995).

68 STUART LEICHENKO ET AL., LOUIS HARRIS AND ASSOCIATES, THE ICD SURVEY OF DISABLED AMERICANS: BRINGNG DISABLED AMERICANS INTO THE MAINSTREAM 9-10 (1986); NEW HARRIS SURVEY MARKS STRONG APPROVAL FOR ADA NINE YEARS AFTER PASSAGE at http://www.nod.org/press.html\#poll (Apr. 15, 1999).

${ }^{69}$ Personal communication with Carol Gill (June 1999). 
recognizable to himself, were he to somehow wake up the next day not as a person of color. He suspects that:

"Racial" ethical identities are ... apparently less conceptually central to who one is than gender ethical identities.

... Nevertheless, even for those for whom being African-American is an important aspect of their ethical identity, what matters to them is almost always not the unqualified fact of that descent, but rather something that they suppose to go with it: the experience of a life as a member of a group of people who experience themselves as - and are held by others to be-a community in virtue of their mutual recognition-and their recognition by others—as people of a common descent. ${ }^{70}$

Appiah, Anna Stubblefield, and Richard Wasserstrom are all philosophers who reject what Stubblefield calls "essentialism" about race.71 Identity, essentialism, and community take on a particular significance when we remember the disability, unlike race or sex, is not usually shared by the members of one's biological or social family, notwithstanding genetic and chromosomal causes of some conditions. Most people with Down syndrome, cystic fibrosis, sickle cell anemia, spina bifida, diabetes, deafness, or blindness-even if manifest in early childhood - do not grow up with parents and siblings who share this characteristic. It is, in fact, the apprehensions about what raising a child with these conditions, and the belief that life for the child and the family will be more negative than positive, that fuel the increasing use of prenatal testing in today's developed nations. Unlike the African-American parent expecting to share bonds with their children that will provide love and community to be some refuge against racism in the outside world, the typical nondisabled prospective parents have no experience with or knowledge of life that includes disability, and they are generally counseled that raising a child with a disability will be an unhappy experience, likened by some to the "burden" of an unwanted child.72 No pamphlets exist in inner-city clinics about the "dangers" of bearing and raising children, despite the fact that children raised in these circumstances are more likely than other children to experience poverty, exposure to drugs, arrest, or incarceration, poor schooling, and unemployment. Such pamphlets do not exist, and should not, because professionals recognize that society, and not biology, accounts for the problems and at least theoretically support social changes to

70 Anthony Appiah, "But Would That Still Be Me?" Notes on Gender, "Race," Ethnicity, as Sources of "Identity, " 87 J. PHIL. 493, 497 (1990).

71 Stubblefield, supra note 8 at 368; Wasserstrom, as cited in Stubblefield, supra note 8 at 368.

72 Jeffrey R. Botkin, Fetal Privacy and Confidentiality, 25 HASTINGS CENT. REP. 32 (Sept.Oct. 1995). 
eradicate those problems. Professionals also are responding to the fact that innercity prospective parents may fear these problems for their future children but may also imagine that love, family, and community make child-rearing worthwhile. Thus, the parents imagine a shared a common identity and community with any future child, a marked contrast with the typical nondisabled prospective parent who fears that a future child's impairment will thwart parental hopes for a fulfilling family life. ${ }^{73}$

Contrast the views of disability as burdensome and disappointing to families expressed by many philosophers and physicians with the findings of recent research showing that most families who raise children with disabilities fare as well as others in overall life satisfaction and enjoyment of their children. ${ }^{74}$ The words of a mother of a young child with a disability eloquently capture what many parents feel after having this experience, one that they may have previously feared or known nothing about:

$[P]$ arents of children with disabilities have often learned to see what is positive within their experience of parenting a disabled child. I would never trade my disabled son's infectious laugh, huge smiles, and enormous hugs for his sister's giftedness. This morning, my husband and I spent three hours at Children's Hospital watching him take aptitude tests and such. We have never taken so much pride in our children as when we watched him try his hardest and come up with answers that made sense in his very special world-which we had the fortunate opportunity to glimpse through his answers.... I don't know any parent of a disabled child who would trade that child in for a "better model" even if we were disappointed at some point to learn about our child's disabilities. ${ }^{75}$

To the extent that an increasing number of families successfully incorporate a child's, parent's, or spouse's impairment into their lives and relationships, they provide the evidence that community can be created by perceiving commonalties as well as differences, by recognizing that commonalties can transcend differences of health and disability status. Regrettably, the history of professional advice about how disabled children would harm families, as well as separate schooling and institutionalization of some members of the disabled population, means that many of today's people with disabilities do not perceive their families as allies or as including them in the family's community. If the social changes

${ }^{73}$ For discussions of disability as inimical to at least some parents' hopes, see William Ruddick, Ways to Limit Prenatal Testing, in PRENATAL TESTING AND DISABILITY RIGHTS 95 (Erik Parens \& Adrienne Asch eds., 2000).

${ }^{74}$ Philip M. Ferguson et al., The Experience of Disability in Families: A Synthesis of Research and Parent Narratives, in PRENATAL TESTING AND DISABIITY RIGHTS, supra note 74 at 72 .

75 See Letter from Professor Ruth Colker, supra note 4. 
envisioned by the Americans with Disabilities Act transform schools and better include people with disabilities in the workforce and the world, perhaps people with disabilities will find more natural community in their family, religious, ethnic, or racial groups, those that traditionally nurture and sustain people facing the larger world. My reflections on disability-as-identity that follow are clearly affected by having been incorporated into family, school, and other meaningful groups throughout my life. As I ponder the Randall Kennedy and Duncan Kennedy assertions about race and affirmative action, along with these philosophical writings on race and sex as central components of identity, trying to draw analogies to my own experience of being a White, Jewish woman with a disability, I find that nothing I read quite captures my own understanding or my own desire for what I want identity to be.

Yes, I suspect that because characteristics like ethnicity, race, sex, and disability are all interwoven in my, or anyone's, experience, I can agree with all those writers who remind us that each characteristic is influenced by the others that make up our lives. Many sensitive people can and do teach and write eloquently about the experience of disability, although they do not themselves live as persons with disabilities or as family members of disabled persons. Although these same people teach excellent disability studies courses and have made significant contributions to the field of disability studies, they may not as easily or routinely infuse insights about disability into their thinking and writing in other topics. My own courses on motherhood, for example, include discussions of women with disabilities as mothers-something I have seen in none of the large numbers of recent books on the experiences of motherhood. ${ }^{76}$ Thus, I suspect that perhaps Duncan Kennedy is right to believe that minority scholars will, whatever their topic, be alert to the implications of their work for minority communities. Bringing such insights into any curriculum constitutes an excellent intellectual argument for affirmative action in academia and elsewhere.

Christopher Nolan, author of a memoir about being an Irish boy with cerebral palsy growing up in the last quarter of the twentieth century, asked by interviewers how he would feel if he could one day get out of his wheelchair, replies that he would get right back in. ${ }^{77}$ Like Nolan, I have had my disability of blindness from birth; I would not, however, give his answer. The possibility of sight is one I neither crave nor fear. Although it might be interesting, pleasurable

76 Illustrative books about motherhood that neglect mothers with disability, although they carefully include many other "marginalized" mothers are: CONCEIVING THE NEW WORLD ORDER: THE GLOBAL POLITICS OF REPRODUCTION (Faye Ginsburg \& Rayna Rapp eds., 1995); MOTHER TROUBLES: RETHINKING CONTEMPORARY MATERNAL DILEMMAS (Julia E. Hanigsberg \& Sara Ruddick eds., 1999); MOTHERING AGAINST THE ODDS: DIVERSE VOICES OF CONTEMPORARY MOTHERS (Cynthia Garcia Coll et al. eds., 1998); and MOTHERING: IDEOLOGY, EXPERIENCE, AND AGENCY (Evelyn Nakano Glenn et al. eds., 1994).

77 CHRISTOPHER NOLAN, UNDER THE EYE OF THE CLOCK: A MEMOIR (2000). 
and convenient, I do not think it would markedly change my commitments, interests, passions, or how I think about the world, human relationships, work, or play. It makes great sense to work with other people who are blind or who have disabilities to combat oppression or to change society. It makes sense to check out reactions to perplexing instances of strained interactions around disability with others who have disabilities, as well as with others who do not. But save for getting advice about one or another piece of adaptive computing technology, I do not find blindness a source of discussion unless I am trying to deal with its misperception in the larger social world. My identity is defined by what I read, not by my means of reading it; Braille is a useful tool, but a taken-for-granted one, as print is to those who use it. The world can make disability central in certain contexts, if $I$ have a day or week of especially assaultive or infantalizing encounters, but working for social change and inclusion necessitates being involved with all sorts of people who care about the intellectual and personal interests that define me-many of which concern topics other than disability.

My dream is much closer to Wasserstrom's dream of a society that makes no life option decisions based on race, sex, or disability status and thus leaves people freer than they are now to find how much of their lives are affected by any one of their many ascribed characteristics. Iris Marion Young, while not essentializing group identity, rejects this individualistic approach to identityformation, saying:

A person's group identities may be for the most part only a background or horizon to his or her life, becoming salient only in specific interactive contexts.

Assuming an aggregate model of groups, some people think that social groups are invidious fictions, essentializing arbitrary attributes. From this point of view problems of prejudice, stereotyping, discrimination, and exclusion exist because some people mistakenly believe that group identification makes a difference to the capacities, temperament, or virtues of group members. This individualist conception of persons and their relation to one another tends to identify oppression with group identification. Oppression... is something that happens to people when they are classified in groups. Because others identify them as a group, they are excluded and despised. Eliminating oppression thus requires eliminating groups....

This book takes issue with that position... [I] tis foolish to deny the reality of groups.... [G]roup differentiation remains endemic.... Even when they belong to oppressed groups, people's group identifications are often important to them, and they often feel a special affinity for others in their group....

Though some groups have come to be formed out of oppression,... group differentiation is not in itself oppressive. ${ }^{78}$

78 YouNG, supra note 65 , at $46-47$. 
Perhaps, despite embracing of disability activism and disability scholarship as a means of social change, I remain involved out of a sense of deep obligation and not excitement. Perhaps the disability affiliation is for me only one of friendships formed in the struggle for change, and although the friendships as well as the work are positive and rewarding, I still do not find this facet of my life and identity inherently interesting.

Paul Kenneth Longmore is eloquent in stating the positive learning and values that, for him, can be attributed to living as a person with a disability when he speaks of values that would change society for everyone if broadly adopted: "not self-sufficiency but self-determination, not independence but interdependence, not functional separateness but personal connection, not physical autonomy but human community."79 Many feminist theorists and critical race authors could sign on to that list of values, coming, as they do, from learning to survive and flourish as persons with little power who must work to glean connections, warmth, and intimacy from a world generally wary of acceptance and welcome to those it sees as "different."

Survival and thriving will indeed be easier if we can move more and more people to appreciate such values, but it will also be easier and more rewarding if people discover and emphasize similarities and commonalities rather than announce their differences as armor to pierce or masks to remove. I draw much solace in the generous writing of Martha Minow, who speaks my language as she struggles with the dilemmas of overemphasizing or ignoring difference and the pitfalls as well as values of identity politics.

Identity politics tends to locate the problem in the identity group rather than the social relations that produce identity groupings.

Judith Butler put the limitations of identity politics bluntly: "You can articulate your identity all you want; you need the damn resources in order to respond to the concrete problems of bodies in pain." To get the resources, you need to work with others; to care about other bodies in pain, you need to move beyond your own circumstances... The potentially multiple, fluid qualities of any person's identity seem to evaporate in the assertion of a single trait. ${ }^{80}$

The human variation approach to disability and impairment could, if adopted, mute the notion of groups of people with disabilities as contrasted to people without them. If environments become more accepting of more members in the population, perhaps there will be less reason for excluded persons to form groups based on oppression because they will be increasingly welcomed into

79 Longmore, supra note 67 , at 9.

${ }^{80}$ MARTHA MINOW, NOT ONLY FOR MYSELF: IDENTTIY, POLITICS AND THE LAW 56-57 (1997). 
family, neighborhood, work, and interest groups. If people continue to find an impairment status worthy of embracing as a part of community membership, it could be out of whatever commonalities beyond oppression they find in that status.

Is there something about impaired capacities-less-than-typical hearing, motor coordination, strength, sight, or skill in understanding and communicating through language - that is unimaginably "neutral" or positive, no matter what the society? Philosophers and bioethicists with interests in disability rights are grappling with this question and as yet, $I$ know of no emerging consensus on what remains of disability as a problematic status apart from an unwelcoming society. We are so far from achieving a welcoming society, that it is about as fanciful as the thought experiments of racial identity and meaning discussed by Appiah, Stubblefield, and Wasserstrom above. ${ }^{81}$

For now, I cannot settle on an answer. I think about Gregory Williams's contribution to this symposium, a portion of which concerns his own musings on similarities and differences between race and disability:

I was challenged by a young man confined [sic] to a wheelchair as to whether his life had been harder than mine. I quickly agreed that, given the choice, I would have much preferred receiving the racial epithets hurled at me, the racial violence directed against me, and the doors closed to me because of my racial heritage than to live his life confined to a wheelchair. 82

I think back to the first time, almost forty years ago, that I read an article questioning whether it was better to be a White, upper-class man who was blind, or to be any man who was Black in the North or South in the pre-Civil Rights Act 1960s. Comparing virulent racism to the limitations he found as a person who was blind, before the movement for Black civil rights had achieved its gains of the 1960 s and before most people with disabilities were aware of any efforts to end their second-class status, Peter Putnam wrote:

Blindness is a confining handicap [sic], but it would not confine the boy to the life in the Negro ghettos that are the shame of our cities, North and South. If he had a

${ }^{81}$ For discussions of the social construction of disability from within the field of bioethics, see Erik Parens \& Adrienne Asch, The Disability Rights Critique of Prenatal Genetic Testing: Reflections and Recommendations, 29 HASTINGS CTR. REP., Sept.-Oct. 1999, at 51; Adrienne Asch, Why I Haven't Changed My Mind about Prenatal Diagnosis: Reflections and Refinements, in PRENATAL TESTING AND DISABLITY RIGHTS 234 (Erik Parens \& Adrienne Asch eds., 2000); Margaret Olivia Little, Cosmetic Surgery, Suspect Norms, and the Ethics of Complicity, in ENHANCING HUMAN TRATS 162 (Erik Parens ed., 1998); and Tom Shakespeare, Arguing About Disability and Genetics, 13 INTERACTION, 2000, at 11, 11-14.

82 Gregory H. Williams, Reflections on the ADA: Rethinking the Past, and Looking toward the Future, 62 Oно ST. L.J. 1, 9 (2000). 
Seeing Eye dog, he would be excluded for his dog, not for his skin. In blindness, he would know moments of humiliating helplessness [sic], but not so bitter as the practice of Jim Crow, the loss of civil rights, or the experience of police brutality Baldwin describes, not in the South, but in New York City.

Yet blindness is a genuine handicap. Blackness is not. The blind man has lost an important sense. The Negro has all his faculties. The handicap of blindness is intrinsic. The handicap of blackness comes from the outside, imposed by force or the threat of force. The handicap of the American Negro has been the American white. ${ }^{83}$

Putnam concludes his ruminations by saying that we should create a society in which it is "no longer a handicap to be black." 84

When I first read those words as a high school student getting involved in the civil rights movement, it seemed to me that it was far easier to be a White, middle-class blind person than to be anyone who was Black. At that time, I had not yet encountered years of employment discrimination and social dismissal that would be part of my adult life. Putnam and myself, as people who are blind, and Gregory Williams, as a person who has self-identified as Black, 85 all were more comfortable with what we knew, with the problems we knew how to fight and survive, than with ones we could only imagine.

Perhaps social constructionists of disability will conclude with Putnam that even in a transformed society where racism, sexism, and disability discrimination are negligible portions of individual and social life, some aspects of life will nonetheless be more difficult or impossible if disabled, and that the human variations of race are easier to accommodate than the variations of differing health or ability. I believe it possible that disability is not entirely reducible to social construction, and that some forms of aesthetic experiences and some sorts of physical activities may be precluded by physiology alone. People who are deaf will not hear music, but they can have the aesthetic experiences of enjoying painting, and those who are blind will not see sunsets, but they can hear birdsongs and oceanwaves; people who use wheelchairs will not run marathons even if they do race in them and cross the finish line before the runners. For now, as we struggle to retain the gains we thought we had won when the ADA became law, as we examine racism and sexism in a post-civil rights world where people of color still earn less than similarly educated Whites, and where women in twocareer families still perform more domestic work and childcare than their male

83 Peter Putnam, If You Had a Choice, JEWISH BRAILLEREV., Oct. 1963, at 25, 30.

84 Id. at 32.

85 See GREgory HoWARD WILLIAMS, LIFE ON THE COLOR LNE: THE TRUE STORY OF A WHITE BOY WHO DISCOVERED HE WAS BLACK (1995), which according to Williams details his "personal transition from a white American to a black American." Williams, supra note 82, at 9. 
partners, we can say that there is much work to do on all fronts. To quote Gregory Williams again on the race/disability comparison:

However the more I thought about it, the more I realized that the issue was not who had the tougher life.... The issue was whether either one of our lives had been affected by external factors that should have had absolutely no impact on our ability to live our lives to the fullest extent possible. ${ }^{86}$

Like feminists and CRT writers, I am not interested in changing my race, sex, or health/ability status; we all need to work with others to gain greater equality, more inclusivity, and greater appreciation of the complexity of humanity in all its variability. The goal is to create a society where it is irrelevant to be blind or Black.

86 Williams, supra note 82 , at 9. 
